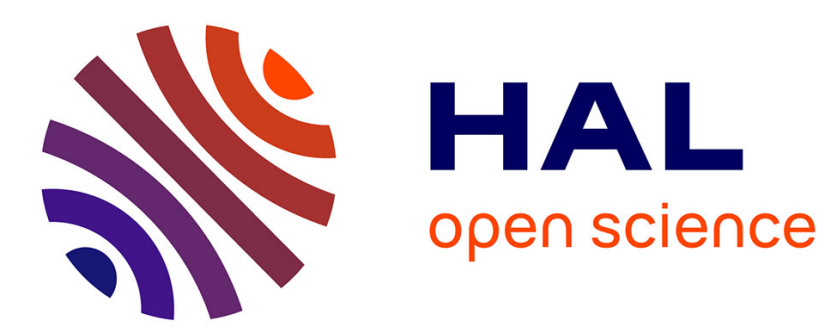

\title{
Physical and mechanical wood properties of 14 timber species from Northeast Mexico
}

Carrillo, Nañez, Garza, Foroughbakhch, Sandoval

\section{To cite this version:}

Carrillo, Nañez, Garza, Foroughbakhch, Sandoval. Physical and mechanical wood properties of 14 timber species from Northeast Mexico. Annals of Forest Science, 2011, 68 (4), pp.675-679. 10.1007/s13595-011-0083-1 . hal-00930816

\section{HAL Id: hal-00930816 https://hal.science/hal-00930816}

Submitted on 1 Jan 2011

HAL is a multi-disciplinary open access archive for the deposit and dissemination of scientific research documents, whether they are published or not. The documents may come from teaching and research institutions in France or abroad, or from public or private research centers.
L'archive ouverte pluridisciplinaire HAL, est destinée au dépôt et à la diffusion de documents scientifiques de niveau recherche, publiés ou non, émanant des établissements d'enseignement et de recherche français ou étrangers, des laboratoires publics ou privés. 


\title{
Physical and mechanical wood properties of 14 timber species from Northeast Mexico
}

\author{
Artemio Carrillo • Miriam Garza • \\ María de Jesús Nañez • Fortunato Garza • \\ Rahim Foroughbakhch $\cdot$ Sadoth Sandoval
}

Received: 11 July 2010 /Accepted: 6 December 2010 /Published online: 15 June 2011

(C) INRA and Springer Science+Business Media B.V. 2011

\begin{abstract}
- Background Thornscrubs are a vegetation type from Northeast Mexico, consisting of 60 to 80 tree and shrub species that are used for a wide range of constructive, decorative and energy purposes. However, basic research of the physical and mechanical wood properties are still needed to establish additional uses and, thereby, increase their value in the timber industry.

- Method In this research, wood from fourteen native species were studied with regard to their basic density (BD), modulus of elasticity (MOE), and modulus of rupture (MOR), as well as the relationships between these three properties.
\end{abstract}

Handling Editor: Jean-Michel Leban

A. Carrillo $(\bowtie) \cdot$ M. Garza $\cdot$ F. Garza

Facultad de Ciencias Forestales,

Universidad Autónoma de Nuevo León,

Carr. Nal. Km. 145,

67700 P.O. Box 041 Linares, Nuevo León, México

e-mail: arte_carr@hotmail.com

\section{Nañez}

Facultad de Ingeniería Mecánica y Eléctrica,

Universidad Autónoma de Nuevo León,

Cd. Universitaria,

San Nicolás de los Garza, Nuevo León, México

R. Foroughbakhch

Facultad de Ciencias Biológicas,

Universidad Autónoma de Nuevo León,

Ap. Post. F-2 Suc. Cd. Universitaria C.P. 66451

San Nicolás de los Garza, Nuevo León, México

S. Sandoval

Instituto Politécnico Nacional,

CIIDIR-Oaxaca. Hornos No. 1003, Col. Noche Buena,

Calle Hornos No. 1003, Col. Noche Buena,

Santa Cruz Xoxocotlan, Oaxaca, México
- Results Results showed that the BD range was $0.48 \mathrm{~g} \mathrm{~cm}^{-3} \pm$ 0.06 to $0.93 \mathrm{~g} \mathrm{~cm}^{-3} \pm 0.07$, the lowest being for Leucaena leucocephala and the highest for Condalia hookeri. MOE range was $6.42 \mathrm{GPa} \pm 1.23$ to $15.13 \mathrm{GPa} \pm 2.72$, corresponding to Diospyros texana and Acacia schaffneri respectively. MOR range was $101 \mathrm{MPa} \pm 16$ to $207 \mathrm{MPa} \pm 33$ for Parkinsonia texana and Acacia schaffneri respectively. Correlations between BD and MOE, BD and MOR, and MOE and MOR were as follows: $r=0.67, r=0.64$ and $r=$ 0.87 respectively.

- Conclusion Values of modulus elasticity and rupture of studied species make them a promising general utility wood that can be recommended for a variety of structural and non-structural uses.

Keywords Density - Modulus of elasticity .

Modulus of rupture $\cdot$ Thornscrub $\cdot$ Vegetation

\section{Introduction}

The forests of Mexico are widely distributed, covering more than 0.6 million $\mathrm{km}^{2}$, representing $32.75 \%$ of the total area of 1.979 million $\mathrm{km}^{2}$ (SEMARNAT 2007). Tamaulipan thornscrub vegetation has an area of about 20 million ha, where around 60 to 80 shrubs and tree species are found, these species being those most used by people living in the rural areas, for either agriculture, livestock, or forest harvesting (Reid et al. 1990). The wood is mainly used for furniture, wagons, tool handles, and different kitchen utensils for rural households, as well as for firewood or charcoal (Folliott and Thames 1983; Meraz et al. 1998). A great number of studies on thornscrub have been reported, but a complete analysis of wood properties has been carried out for only a few species (Carrillo et al. 2011). The main objective of the present 
research is to reassess the available information such as basic density (BD), modulus of elasticity (MOE) and modulus of rupture (MOR) for 14 timber species from Northeast Mexico, and to establish a basis for better utilization of these species.

\section{Material and methods}

\subsection{Species and sample trees}

The 14 timber species used for this research were selected from those most preferred and used by the rural population because of their availability, natural durability, and good construction quality (Wolf and Perales 1985; Carrillo et al. 2008; Villalón and Carrillo 2010). Three straight trees from each species having no defect, insect, or mechanical damage, were randomly sampled from an area located at $99^{\circ} 11^{\prime} 56^{\prime \prime}$ and $25^{\circ} 08^{\prime} 59^{\prime \prime}$ in Linares, Nuevo León, Mexico. The material for physical and mechanical tests was obtained from heartwood in the bole zone of $0.3 \mathrm{~m}$ to $1.3 \mathrm{~m}$ above the tree base, according to Ramos-Alvarez and Díaz-Gómez (1981). The averages of tree height and diameter at breast height obtained in the sites of each species are presented in Table 1.

\subsection{Sample preparation}

After tree logging, wood samples were prepared and conditioned according to the German standard DIN 52180 (1994). A total of 30 samples, size $10 \times 20 \times 20 \mathrm{~mm}$ (longitudinal $\times$ radial $\times$ tangential directions respectively) were cut from each species (ten samples per tree) and tested to determine BD (dry mass divided by green volume) in accordance with DIN 52182 (1978). MOE was determined using also 30 specimens from each species (ten samples per tree), measuring $100 \times 5 \times$ $10 \mathrm{~mm}$. The MOE test was performed on a universal Tinius Olsen machine once samples reached constant weight at $65 \%$ moisture content and $20 \pm 3^{\circ} \mathrm{C}$, using three-point static bending where annual rings were orientated horizontally according to DIN 52186 (1978); the load $(F)$ was applied at a uniform rate $\left(5 \mathrm{~mm} \mathrm{~min}^{-1}\right)$ in the direction of the narrow side at the centre of the sample span. Also, MOR was determined during the same test using the maximum load at the break point as the condition of rupture. All calculations were performed using Statistical Analysis System (SAS C2004, Version 9.1.2). BD, MOE and MOR of the species were compared, and correlations between $\mathrm{BD}$ and $\mathrm{MOE}, \mathrm{BD}$ and MOR as well as MOE and MOR were developed.

\section{Results and discussion}

BD from the fourteen timber species is summarized and categorized in Table 2 following Echenique and Díaz (1969). Two species reached class 10, "extremely heavy", corresponding to density higher than $0.86 \mathrm{~g} \mathrm{~cm}^{-3}:$ C. hookeri was the densest species $\left(0.93 \mathrm{~g} \mathrm{~cm}^{-3} \pm 0.07\right)$ and E. ebano the

Table 1 Tree characteristics of 14 timber species from Northeast Mexico

\begin{tabular}{|c|c|c|c|c|c|}
\hline \multirow[t]{2}{*}{ Latin name } & \multirow[t]{2}{*}{ Common name } & \multirow[t]{2}{*}{ Family } & \multirow[t]{2}{*}{ Use* $^{*}$} & \multicolumn{2}{|c|}{ Average } \\
\hline & & & & Tree height $(\mathrm{m})$ & $\mathrm{DBH}^{* *}(\mathrm{~m})$ \\
\hline Acacia amentacea DC. & Gavia & Leguminosae & $\mathrm{L}^{1 * * *}$ & 3.5 & 0.20 \\
\hline Acacia farnesiana (L.) Willd. & Huizache & Leguminosae & $\mathrm{L}$ & 4.5 & 0.35 \\
\hline Acacia schaffneri var. schaffneri (S. Watson) F.J. Herm. & Hizache chino & Leguminosae & $\mathrm{L}, \mathrm{C}$ & 3.5 & 0.25 \\
\hline Condalia hookeri M.C. Johnst. & Brasil & Rhamnaceae & $\mathrm{L}^{1}, \mathrm{C}^{1}$ & 5.8 & 0.35 \\
\hline Cordia boissieri DC & Anacahuita & Boraginaceae & $\mathrm{L}^{1}$ & 4.4 & 0.30 \\
\hline Diospyros palmeri Eastw. & Chapote blanco & Ebenaceae & $\mathrm{L}^{1}$ & 5.7 & 0.30 \\
\hline Diospyros texana Scheele & Chapote obscuro & Ebenaceae & $\mathrm{L}$ & 6.2 & 0.35 \\
\hline Ebenopsis ebano (Berl.) Barneby \& Grimes & Ebano & Leguminosae & $\mathrm{L}^{1}, \mathrm{C}^{1}$ & 6.9 & 0.35 \\
\hline Havardia pallens (Benth.) Britton \& Rose & Tenaza & Leguminosae & $\mathrm{L}^{1}$ & 4.1 & 0.20 \\
\hline Helietta parvifolia (Gray) Benth. & Barreta & Rutaceae & $\mathrm{L}^{1}$ & 4.8 & 0.20 \\
\hline Leucaena leucocephala ssp. Glabrata (Rose) S. Zárate & Leucaena & Leguminosae & $\mathrm{L}$ & 5.7 & 0.20 \\
\hline $\begin{array}{l}\text { Parkinsonia texana (A. Gray) } \\
\text { S. Watson var. Macra (I.M. Johnston) Isely. }\end{array}$ & Palo verde & Leguminosae & NR & 6.4 & 0.28 \\
\hline $\begin{array}{l}\text { Prosopis laevigata } \\
\text { (Humb. \& Bonpl. ex. Willd.) M.C. Johnst. }\end{array}$ & Mezquite & Leguminosae & $\mathrm{L}^{1,2}, \mathrm{C}^{1,2}$ & 7.2 & 0.45 \\
\hline Sideroxylon celastrinum (Kunth) Pennington & Coma & Sapotaceae & $\mathrm{L}$ & 4.7 & 0.25 \\
\hline
\end{tabular}

*Uses: $\mathrm{L}=$ firewood, $\mathrm{C}=$ Charcoal, $\mathrm{NR}=$ Non reported uses,

** Diameter at breast height

*** Source: ${ }^{1}$ Medina (2002), ${ }^{2}$ Carrillo et al. (2011) 


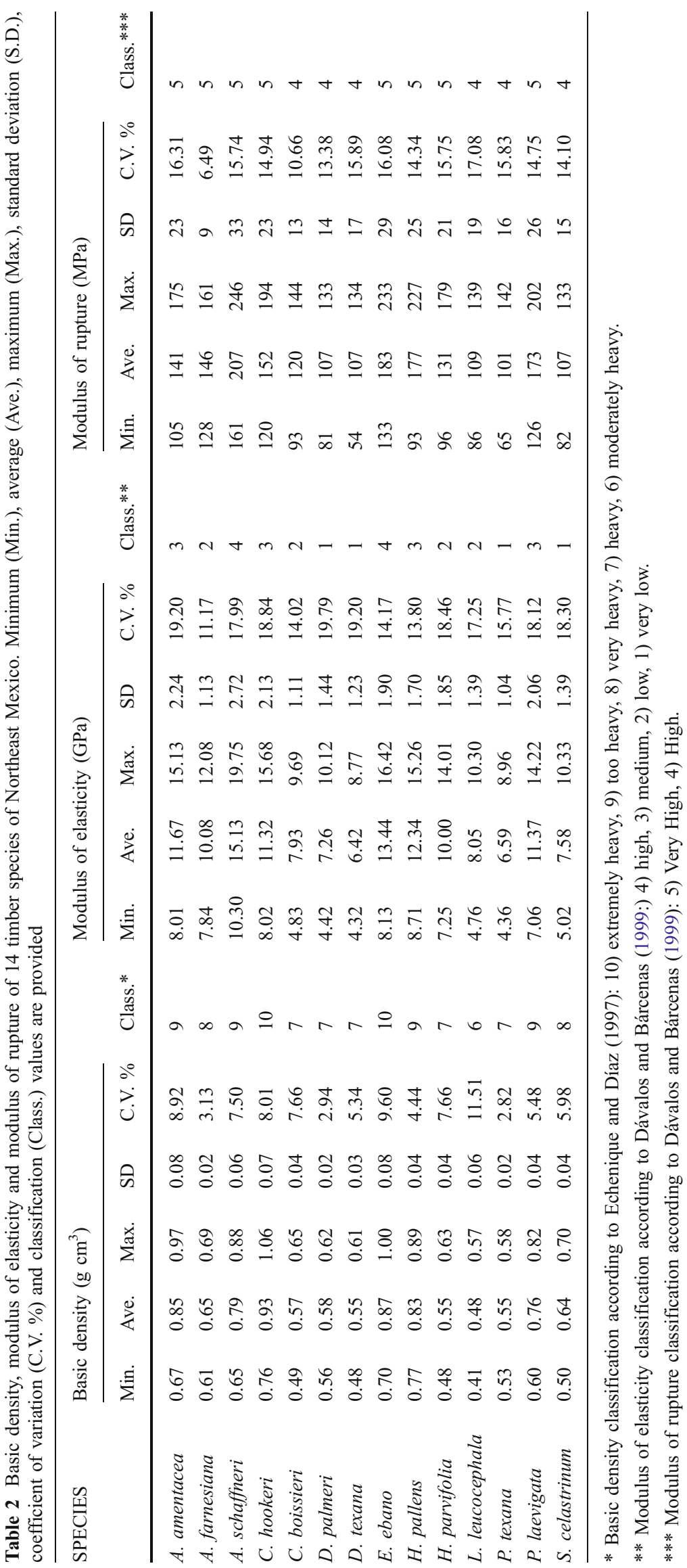


second $\left(0.87 \mathrm{~g} \mathrm{~cm}^{-3} \pm 0.08\right)$. Four species were found for Class 9, "too heavy", with values from $0.72 \mathrm{~g} \mathrm{~cm}^{-3}$ to $0.86 \mathrm{~g}$ $\mathrm{cm}^{-3}$ : A. amentacea $\left(0.85 \mathrm{~g} \mathrm{~cm}^{-3} \pm 0.08\right), H$. pallens $(0.83 \mathrm{~g}$ $\left.\mathrm{cm}^{-3} \pm 0.04\right)$, A. schaffneri $\left(0.79 \mathrm{~g} \mathrm{~cm}^{-3} \pm 0.06\right)$ and $P$. laevigata $\left(0.76 \mathrm{~g} \mathrm{~cm}^{-3} \pm 0.04\right)$. Two species fell into Class 8 , "very heavy" $\left(0.60 \mathrm{~g} \mathrm{~cm}^{-3}\right.$ to $\left.0.72 \mathrm{~g} \mathrm{~cm}^{-3}\right)$ : A. farnesiana $\left(0.65 \mathrm{~g} \mathrm{~cm}^{-3} \pm 0.02\right)$ and $S$. celastrinum $\left(0.64 \mathrm{~g} \mathrm{~cm}^{-3} \pm\right.$ $0.04)$. Five species were classified into Class 7 , "heavy" $\left(0.50 \mathrm{~g} \mathrm{~cm}^{-3}\right.$ to $\left.0.60 \mathrm{~g} \mathrm{~cm}^{-3}\right)$ : D. palmeri $\left(0.58 \mathrm{~g} \mathrm{~cm}^{-3} \pm 0.02\right)$, C. boissieri $\left(0.57 \mathrm{~g} \mathrm{~cm}^{-3} \pm 0.04\right)$, P. texana $\left(0.55 \mathrm{~g} \mathrm{~cm}^{-3} \pm\right.$ $0.02), H$. parvifolia $\left(0.55 \mathrm{~g} \mathrm{~cm}^{-3} \pm 0.04\right)$ and $D$. texana $\left(0.55 \mathrm{~g} \mathrm{~cm}^{-3} \pm 0.03\right)$. One species was labelled Class 6 , "moderately heavy" $\left(0.42 \mathrm{~g} \mathrm{~cm}^{-3}\right.$ to $\left.0.50 \mathrm{~g} \mathrm{~cm}^{-3}\right): L$. leucocephala $\left(0.48 \mathrm{~g} \mathrm{~cm}^{-3} \pm 0.06\right)$. Information describing $\mathrm{BD}$ for these fourteen species is so far almost unavailable; only a few studies have been published. Correa-Méndez et al. (2008) worked with trees growing in a similar place to that used for this research, located northeast of the State of Tamaulipas. They stated basic density values higher than reported in this research for species such as E. ebano $\left(0.97 \mathrm{~g} \mathrm{~cm}^{-3}\right)$, H. pallens $\left(0.76 \mathrm{~g} \mathrm{~cm}^{-3}\right)$ and C. boissieri $\left(0.58 \mathrm{~g} \mathrm{~cm}^{-3}\right)$. Carrillo et al. (2010) reported wood air-dry density for $P$. laevigata from four different sites at $12 \%$ moisture content ranging from $0.79 \mathrm{~g} \mathrm{~cm}^{-3}$ to $0.91 \mathrm{~g} \mathrm{~cm}^{-3}$. Gillah and Ishengoma (1993) reported a value of $0.54 \mathrm{~g} \mathrm{~cm}^{-3}$ for L. leucocephala from plantations. According to basic densities detected in this research, the management of thornscrub species should be focussed on promoting their industrial use, especially those from classes 7 to 9 . However, less dense species in class 6 such as L. leucocephala could be integrated into multipurpose plantations for wood biomass production.

Results of MOE are summarized and categorized in Table 2. This table shows a great MOE variation between thornscrub species. According to the classification for five classes of Mexican timber species developed by Dávalos and Bárcenas

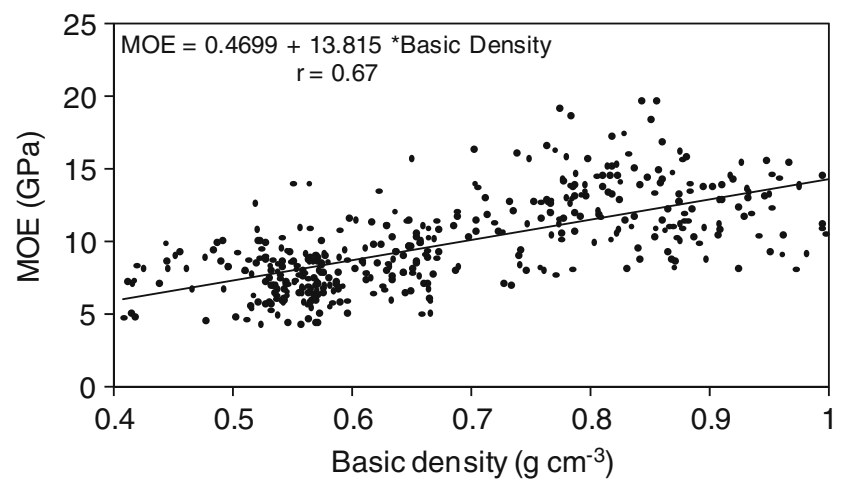

Fig. 1 Relationship between MOE and BD from 14 species of Northeast Mexico

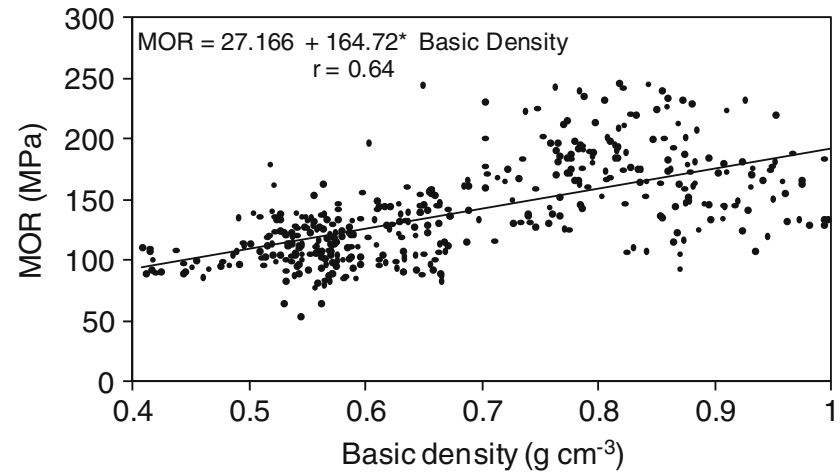

Fig. 2 Relationship between MOR and BD from 14 species of Northeast Mexico

(1999), the Thornscrub species fall into four classes. For Class 4, "high", the species were A. schaffneri (15.13 GPa \pm 2.72) and E. ebano (13.44 $\mathrm{GPa} \pm 1.90)$. For Class 3, "medium", four species were found: $H$. pallens $(12.34 \mathrm{GPa} \pm$ 1.70), A. amentacea (11.66 GPa \pm 2.24$)$, P. laevigata (11.36 GPa \pm 2.06 ), and C. hookeri (11.32 GPa \pm 2.13 ). Four species were labelled Class 2, "low": A. farnesiana $10.07 \mathrm{GPa} \pm 1.12): H$. parvifolia (10.00 GPa \pm 1.84$) ; L$. leucocephala (8.05 GPa \pm 1.39$)$, and C. boissieri (7.93 GPa \pm 1.11). In Class 1, "very low", four species were found: $S$. celastrinum (7.58 GPa \pm 1.38$)$, D. palmeri (7.26 GPa \pm 1.44$)$, P. texana (6.58 GPa \pm 1.04$)$, and D. texana (6.42 $\mathrm{GPa} \pm 1.23)$. For MOE, values ranging from $6.58 \mathrm{GPa}$ to $9.67 \mathrm{GPa}$ for $P$. laevigata were reported by Carrillo et al. (2010).

Results of MOR are summarized and categorized in Table 2. Average values ranged from "high" to "very high" for the 14 species according to the classification system of Dávalos and Bárcenas (1999). For class 5, "very high", eight species were found: A. schaffneri (207 MPa \pm 33$)$, E. ebano (183 MPa \pm 29$)$, H. pallens (177 $\mathrm{MPa} \pm 25)$, P. laevigata (173 $\mathrm{MPa} \pm 26), C$. hookeri (152 $\mathrm{MPa} \pm 23)$, A. farnesiana (146 $\mathrm{MPa} \pm 9), A$. amentacea (141 $\mathrm{MPa} \pm 23)$, and $H$. parvifolia (130 MPa \pm 21$)$.

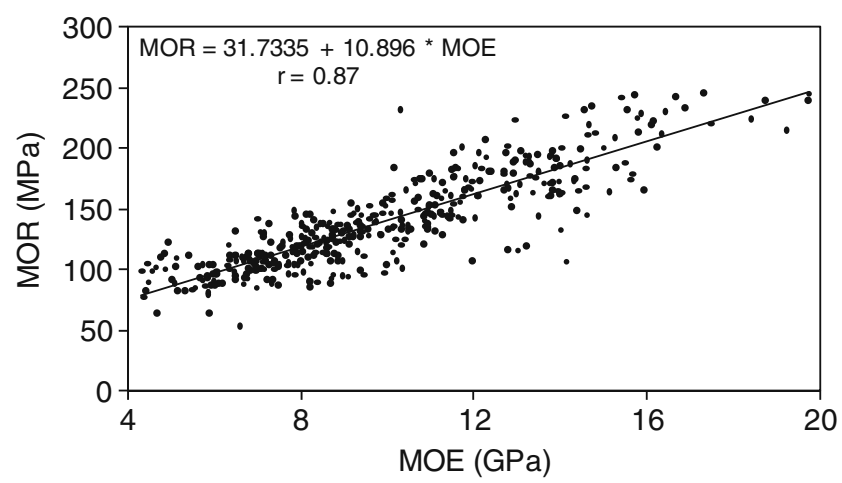

Fig. 3 Relationship between MOR and MOE from 14 species of Northeast Mexico 
Six species were labelled Class 4, "high": C. boissieri (120 $\mathrm{Mpa} \pm 13)$; L. leucocephala (109 MPa \pm 19$)$, D. texana $(107 \mathrm{MPa} \pm 17)$, D. palmeri (107 $\mathrm{MPa} \pm 14)$, S. celastrinum $(107 \mathrm{MPa} \pm 15)$, and $P$. texana (101 $\mathrm{MPa} \pm 16)$. Values ranging from $97 \mathrm{MPa}$ to $126 \mathrm{MPa}$ for $P$. laevigata were reported by Carrillo et al. (2010).

Wood density is one of the most important wood characteristics, and it is used as an indicator of wood quality (Freyburger et al. 2009). Determination of some physical and mechanical properties is very time-consuming (Kokutse et al. 2010). The relationships of BD with MOE and MOR are shown in Figure 1. The model MOE $=469.92+13.815 * \mathrm{BD}$, $p<0.05$ justifying the correlation coefficient of $r=0.67$ was found between the MOE and $\mathrm{BD}$, a value of $r^{2}=0.50$ in this relationship was detected by Dávalos and Bárcenas (1999) after the evaluation of 119 Mexican timber species in dry condition. On the other hand, the relationship between MOR and BD (Fig. 2) was described based on the model (MOR= $27.116+164.72 * \mathrm{BD}, p<0.05)$ with a correlation coefficient of $r=0.64$. In this study, simple linear regression analysis showed that MOR was highly correlated with MOE for the fourteen thornscrub species $(r=0.87, p<0.05)$, justifying the model $\mathrm{MOR}=31.7335+0.01090 * \mathrm{MOE}$ as is shown in Figure 3. The correlations found in this research were similar to those previously reported for hardwood species, showing high relationships between MOE and MOR for species such as Eucalyptus camaldulensis, Khaya senegalensis, Tamarix articulate, and Casuarina spp. (Ei-Osta et al. 1979).

\section{Conclusion}

Values of BD, MOE and MOR for the majority of species are reported here for the first time. The relatively high correlation between modulus of elasticity and rupture can be used for suitable prediction of bending strength based on modulus of elasticity.

The high density values found for some species such Condalia hookeri, Ebenopsis ebano, Acacia amentacea and Havardia pallens indicated the high quality in terms of mechanical properties of these species. High modulus elasticity and rupture for Acacia schaffneri, Ebenopsis ebano, Havardia pallens and Acacia amentacea, make these species a promising general utility wood that can be recommended for a variety of structural and non-structural uses. The establishment of an appropriate silvicultural management of the species mentioned above is highly recommended.

Acknowledgments This work was supported by The Improvement of Professors Program (PROMEP) and The Scientific and Technological Research Support Program (PAYCIT). The authors also express thanks to Manuelita María González Ramos for language revision.

\section{References}

Carrillo A, Mayer I, Koch G, Hapla F (2008) Wood anatomical characteristics and chemical composition of Prosopis laevigata grown in the northeast of Mexico. IAWA J 29:25-34

Carrillo A, Mayer I, Koch G, Hapla F (2011) Durabilidad de la madera de Prosopis laevigata y efecto de sus extractos en hongos de la madera. Madera y Bosques (Accepted).

Carrillo A, Hapla F, Mayer I, Gerald K, Foroughbakch R (2010) Differences in physical and mechanical wood properties of mesquite (Prosopis laevigata) in four location in northeast Mexico. Int J Agr Environ Biotechnol 2:225-234

Correa Méndez F, Forona Ambriz A, Fuentes Salinas M, Borja de la Rosa A (2008) Características tecnológicas de 16 maderas del Estado de Tamaulipas, que influyen en la fabricación de tableros de partículas y de fibras. Revista Chapingo 14:65-71

Dávalos R, Bárcenas G (1999) Clasificación de las propiedades mecánicas de las maderas mexicanas en condición "seca". Madera y Bosques 5:61-69

DIN 52180. (1994) Testing of wood — Sampling and cutting Principles. Deutsches Institut für Normung e. V. Berlin

DIN 52182. (1978) Testing of wood; determination of density. Deutsches Institut für Normung e. V. Berlin.

DIN 52186. (1978) Testing of wood; bending test. Deutsches Institut für Normung e. V. Berlin.

Echenique MR, Díaz V (1969) Algunas características tecnológicas de la madera de once especies mexicanas. Secretaría de Agricultura y Recursos Hidráulicos. Subsecretaría Forestal y de la Fauna. Inst. de Investigaciones Forestales, Boletín Técnico No. 27

Ei-Osta M, Badran O, El-Wakeel A (1979) Prediction of modulus of rupture from modulus of elasticity for some egyptian hardwoods. Wood Fiber Sci 11:147-154

Folliott PF, Thames JL (1983) Manual sobre taxonomía de Prosopis en México, Perú y Chile, Rome

Freyburger C, Longuetaud F, Mothe F, Constant T, Leban JM (2009) Measuring wood density by means of X-ray computer tomography. Ann For Sci 66:804

Gillah P, Ishengoma R (1993) Kraft pulping of Leucaena leucocephala grown in Morogoro, Tanzania. Eur J Wood Wood Prod 51:353-356

Kokutse AD, Brancheriau L, Chaix G (2010) Rapid prediction of shrinkage and fibre saturation point on teak (Tectona grandis) wood based on near-infrared spectroscopy. Ann For Sci 67:403

Medina GR (2002) Evaluación de las especies vegetales del matorral en la sierra de San Carlos, Tamaulipas, México. Thesis. Facultad de Ciencias Forestales, UANL, Linares, N.L. Marzo 2002. 57 pp.

Meraz VS, Orozco J, Lechuga JA, Cruz F, Veron J (1998) El Mezquite, árbol de gran utilidad. Ciencias 51:20-21

Ramos-Alvarez CH, Díaz-Gómez V (1981) Instructivo para recolectar muestras de madera para estudios tecnológicos. In: Instituto Nacional de Investigaciones Forestales. SARH, México

Reid N, Jorge M, Bayer-Munche P (1990) Utilization of shrubs and trees for browse fuelwood and timber in the tamaulipan thurnscrub, northeastern Mexico. Forest Ecol Manage 36:61-69

SEMARNAT (2007) Sistema Nacional de Información Ambiental y de Recursos Naturales. http://www.semarnat.gob.mx/informacio nambiental/Pages/sniarn.aspx.

Villalón H, Carrillo A (2010) Plantas productoras de leña y carbón. In: Alvarado-Vázquez M.A., Rocha-Estrada A., and Moreno-Limón S. eds. De la lechuguilla a las biopelículas vegetales: las plantas útiles de Nuevo León. Monterrey, Nuevo León (in press).

Wolf F, Perales F (1985) Durabilidad natural de la madera de algunas especies del matorral del noreste de México. Linares, Nuevo León., UANL. Reporte Científico No.3. 20 pp. 